УДК 911.52:581.543

ТЕНДЕНЦИИ ВЕСЕННЕГО РАЗВИТИЯ РАСТИТЕЛЬНОСТИ

В УСЛОВИЯХ ЛАНДШАФТНОГО РАЗНООБРАЗИЯ УРАЛА В КОНТЕКСТЕ КЛИМАТИЧЕСКИХ ИЗМЕНЕНИЙ

${ }^{1}$ Гурьевских О.Ю., ${ }^{1}$ Иванова Ю.Р., ${ }^{1}$ Скок Н.В., ${ }^{1}$ Юровских А.М., ${ }^{1}$ Янцер О.В., ${ }^{2}$ Кянцева Н.Б., ${ }^{3}$ Прокошева И.В., ${ }^{4}$ Тертица Т.К.

${ }^{1}$ ФГБОУ ВО «Уральский государственный педагогический университет, Екатеринбург, e-mail: ksenia_yantser@bk.ru;

${ }^{2}$ Ильменский государственный заповедник им. В.И. Ленина, Миасс;

${ }^{3}$ ФББУ «Заповедник Вишерский», Красновишерск;

${ }^{4}$ Печоро-Илычский государственный природный биосферный заповедник, Якиа

Статья посвящена результатам исследований тенденций весеннего развития растительности в ландшафтных областях и провинциях Северного, Среднего и Южного Урала с 1925 по 2019 г. По данным архивов РГО, фондовых материалов заповедников и метеостанций, а также экспедиционных исследований проведен расчет метеорологических показателей, средних многолетних дат наступления явлений и их трендов. При анализе массива апробирована методика отбора корректных данных при расчете количественных показателей весенних фенологических процессов. В качестве основного материала для анализа использованы данные по климатическим и фенологическим явлениям, характеризующим начало, середину и окончание весны: начало сокодвижения у березы (Betula pubescens; Betula Pendula Roth.), начало зеленения березы и начало цветения черемухи (Padus avium Mill.). В работе приведены широтные, долготные и высотные градиенты и скорости продвижения явлений в пространстве, установлены границы весны во всех ландшафтных провинциях. Особый акцент в статье сделан на тенденциях изменения термического режима и весеннего развития березы и черемухи по провинциям. Установлена зависимость между сроками наступления весенних явлений, пороговыми значениями температур $+5^{\circ},+10^{\circ},+12^{\circ}$ и $+14^{\circ}$, а также влияние сумм положительных температур на явления-феноиндикаторы. Установлены отрицательные тренды изменения среднегодовой температуры воздуха и весенних процессов у березы и черемухи, свидетельствующие о смещении сроков наступления сезонных явлений на более ранние и характеризующие динамику пространственно-временной структуры природных комплексов Урала. Однонаправленные, но различные величины изменения трендов определяются разнообразием ландшафтной структуры.

Ключевые слова: ландшафтные провинции Урала, весенние фенологические явления, динамика, температурный режим, феноиндикация, тренды сезонных явлений

\title{
TRENDS IN THE SPRING DEVELOPMENT OF VEGETATION IN THE CONTEXT OF THE LANDSCAPE DIVERSITY OF THE URALS IN THE CONTEXT OF CLIMATIC CHANGES
}

\author{
${ }^{1}$ Guryevskikh O.Yu., ${ }^{1}$ Ivanova Yu.R., ${ }^{1}$ Skok N.V., ${ }^{1}$ Yurovskikh A.M., \\ ${ }^{1}$ Yantser O.V., ${ }^{2}$ Kuyantseva N.B., ${ }^{3}$ Prokosheva I.V., ${ }^{4}$ Tertitsa T.K. \\ ${ }^{1}$ Ural State Pedagogical University, Yekaterinburg,e-mail: ksenia_yantser@bk.ru; \\ ${ }^{2}$ V.I. Lenin Ilmensky State Reserve, Miass; \\ ${ }^{3}$ Vishersky Reserve, Krasnovishersk; \\ ${ }^{4}$ Pechoro-Ilych State Natural Biosphere Reserve, Yaksha
}

\begin{abstract}
The article deals with the results of research trends in the spring development of vegetation in the landscape areas and provinces of the Northern, Middle and South Urals from 1925 to 2019. According to the archives of The Russian Geographical Society, stock materials of nature reserves and meteorological stations, as well as expeditionary studies, the calculation of meteorological indicators, the average perennial dates of the occurrence of phenomena and their trends. When analyzing the array, the method of selecting corrective data is tested when calculating quantitative indicators of spring phenology processes. As the main material for the analysis, data on climatic and fenological phenomena, characterizing the beginning, middle and end of spring: beginning of birch sap flow (Betula Pubescens; Betula Pendula Roth.), beginning of the blooming leaves birch and the beginning of the blossom of the cherry (Padus Avium Mill.). The paper presents latitudinal, long-term and high-rise gradients and the speed of promotion of phenomena in space, the boundaries of spring are installed in all landscaped provinces. A special emphasis in the article is made on the trends in the thermal regime and spring development of birch and cherry for the provinces. The relationship is established between the timing of the onset of spring phenomena, thresholds of temperatures $+5^{\circ} \mathrm{C},+10^{\circ} \mathrm{C},+12^{\circ} \mathrm{C}$ and $+14^{\circ} \mathrm{C}$, as well as the effect of the sums of positive temperatures on the phenoindicator phenomena. Negative trends have been established changes in the average annual air temperature and spring processes in birch and cherry, indicating the displacement of the timing of seasonal phenomena earlier and characterizing the dynamics of the spatial-temporal structure of natural complexes of the Urals. Unidirectional, but various variables of trends are determined by a variety of landscape structure.
\end{abstract}

Keywords: landscape provinces of the Urals, spring phonological phenomena, dynamics, temperature regime, fenoindication, seasonal trends 
Познание функционирования ландшафтов происходит через изучение отдельных процессов перемещения вещества, энергии и информации. Физико-географические процессы характеризуются качественными и количественными показателями, отражающими состояния природных комплексов. Устойчивая смена режима функционирования ландшафта проявляется ритмически, происходит согласованно и физиономично проявляется в динамике фитокомпонента. Исследование ее внешних проявлений приводит к установлению пространственных фенологических закономерностей, что служит географической характеристикой функционирования ландшафтов разного уровня и ранга.

Изменения климата и метеорологических показателей для территории России характеризуются повышением среднегодовой температуры воздуха (СГТВ) начиная с 1976 г. В оценочных докладах об изменениях климата отмечается неравнозначное увеличение температуры приземного воздуха по регионам в разные сезоны. По данным Росгидромета, потепление по России за ХХ в. составило $1,29^{\circ} \mathrm{C}$ [1].

В последние годы особую актуальность приобретает изучение реакции растений на изменение климатических показателей с помощью программ многолетних фитофенологических исследований. Отмечается преобладание ярко выраженных фенологических тенденций, подтверждающих современное потепление климата. Вслед за повышением температуры происходит смещение дат весенних фенологических явлений на более ранние сроки. Однако данная тенденция характерна не для всех видов и сообществ растений. Наиболее существенное влияние климатических изменений характерно для растительности горных территорий $[2 ; 3]$.

Целью данной работы является анализ тенденций смещения сроков наступления весенних фенологических явлений в сопоставлении с характером многолетних изменений температурных показателей. Исследование включает анализ весенней динамики ландшафтных провинций $\mathrm{Ce}$ верного, Среднего и Южного Урала в связи с климатическими изменениями в XX и начале XXI вв.

\section{Материалы и методы исследования}

Инвариантной основой для анализа тенденций весеннего развития растительности служат результаты физико-географическо- го районирования Урала. Существует несколько признанных схем физико-географического районирования Урала, которые разработаны выдающимися представителями региональных ландшафтных школ: Л.Д. Долгушин (1955), А.М. Оленев (1959), А.Г. Чикишев (1966), А.А. Макунина (1974), В.И. Прокаев (1983), А.А. Чибилев (2011), А.В. Шакиров (2011) и др. [4; 5]. Комплексностью и принципиальной обоснованностью отличается [6] генетическая классификация и схема физико-географического районирования Новоземельско-Уральской равнинно-горной страны В.И. Прокаева [7], на основе теоретических построений которой проанализировано ландшафтное разнообразие региона. При выявлении эмерджентных эффектов с позиции функционально-динамического подхода за основу принята концепция многорядной системы природных комплексов В.И. Прокаева, интегрированная в методологию полимасштабного анализа структуры ландшафта, разработанную А.В. Хорошевым [8].

Специфика Новоземельско-Уральской равнинно-горной страны обусловлена генетическими факторами формирования территории под действием эндогенной и экзогенной энергии. В природе Урала ярко проявляются закономерности физикогеографической дифференциации разного порядка: планетарные - тектогенная, климатогенная: зональная и секторная; региональные - высотно-поясная, барьерная, солярно-экспозиционная; местные топологические, связанные со спецификой местоположения в пределах форм и элементов рельефа, а также обусловленные антропогенным фактором. Физико-географическое районирование территории основано на принципах индивидуальной классификации природных комплексов, выполненной на генетической основе. При определении иерархического ранга природных комплексов применены критерии сложности и оригинальности в пределах генетических рядов тектогенных, климатогенных и ландшафтных геосистем.

Основными единицами, отвечающими задаче анализа тенденций сезонной динамики природных комплексов для установления климатических изменений, явились ландшафтная область и ландшафтная провинция. Ландшафтная область, включающая природные комплексы одной азональной страны, однородные по зональным и секторным особенностям, характеризуется основными типичными характеристиками гидротерми- 
ческих показателей: планетарным количеством тепла и влаги и их соотношением, т.е. энергетическими предпосылками для протекания физико-географических процессов. По странам изменяются главные черты геологического строения и рельефа и, следовательно, основные вещественные предпосылки для протекания этих процессов. Кроме того, геолого-геоморфологические факторы вносят существенные коррективы в секторно-зональный гидротермический фон, перераспределяя планетарные количества тепла и влаги по формам и элементам рельефа. Особенно велика роль геолого-геоморфологических факторов в горах, где зональность и секторность сильно осложняются высотной поясностью и проявляются в зональных и секторных типах ее структуры [7]. Страны, зоны и секторы - генетические единства, поэтому, учитывая секторную и зональную однородность природных комплексов Урала внутри ландшафтных областей, возможно объяснение ряда климатических параметров при характеристике тенденций сезонной динамики вообще и весенних явлений в частности.

Обследованная территория Северного, Среднего и Южного Урала расположена в пределах пяти ландшафтных областей Новоземельско-Уральской равнинно-горной страны: таежной умеренно континентальной, таежной континентальной, лесостепной умеренно континентальной, лесостепной континентальной и степной континентальной. Ландшафтные области Урала, сочетающие в себе сопоставимую степень тектогенной и климатогенной однородности, выделяются методом «наложения» границ односторонних природных комплексов сопоставимого ранга: страны, зоны и сектора [9]. Причем секторные факторы дифференциации приводят к обособлению в пределах таежной и лесостепной зон Северного, Среднего и Южного Урала двух зонально однородных ландшафтных областей - умеренно континентальной и континентальной.

Ландшафтная область, особенно выделяемая в горах, представляет собой достаточно крупное и закономерно разнородное территориальное образование. Например, таежные области Урала включают не только горную полосу, но и предгорья, и Зауральский пенеплен, отличающиеся не только характером геолого-геоморфологической основы, но и различиями остальных природных компонентов. Поэтому в качестве основной физико-географической единицы для анализа тенденций весеннего развития растительности выбрана единица более низкого ранга - ландшафтная провинция. Эта геосистема объединяет природные комплексы, сходные по подзональным, секторным и неотектонико-орографическим особенностям. Геолого-геоморфологическая основа провинций характеризуется преобладанием одного морфометрического типа горного или равнинного рельефа, обусловленного общностью неотектонического режима; а в горах - сходством структуры высотной поясности. Ландшафтные провинции обособляются в результате пространственного наложения факторов обособления тектогенных краев, подзон и климатических подсекторов. Таежная зона Урала характеризуется наибольшим ландшафтным разнообразием, обусловленным значительной протяженностью территории с севера на юг, меридиональным направлением геологических структур и форм рельефа в пределах Северного и Среднего Урала. Меридиональная вытянутость хребтов определяет секторную и барьерную дифференциацию территории и, как результат, деление Западных и Восточных макросклонов границей Восточно-Русского и Западно-Сибирского подсекторов, которая одновременно является границей умеренно континентального и континентального секторов Евразии. Восточно-Русский подсектор характеризуется умеренно-континентальным климатом и годовой амплитудой температуры воздуха 28-33, а Западно-Сибирский - континентальным климатом с годовой амплитудой $34-44^{\circ}$ [7]. В результате наложения факторов тектогенной и климатогенной дифференциации в пределах таежной умеренно континентальной ландшафтной области Урала обособляется четыре провинции: Щугоро-Вишерская западных предгорий Северного Урала, Среднегорная ЩугороУсьвинская Северного Урала, Косьво-Юрюзанская западных предгорий Среднего Урала, Низкогорная провинция Среднего Урала. Таежная континентальная область Урала включает три ландшафтные провинции: Ятрия-Лобвинскую восточных предгорий Северного Урала, Исетско-Лялинскую восточных предгорий Среднего Урала и Тагило-Пышминскую Зауральского пенеплена.

В пределах лесостепной ландшафтной области Урала сложность ландшафтного строения определяется геолого-геоморфологическим фактором, хотя обособление провинций также происходит на однородном секторно-зональном фоне. В умеренно 
континентальных условиях выделяется Западная предгорно-среднегорная провинция Южного Урала. В условиях континентального сектора сформировались природные комплексы двух ландшафтных провинций: Восточной предгорно-среднегорной Южного Урала и Исетско-Уйской провинции Зауральского пенеплена.

Степная ландшафтная область обособилась в условиях засушливости и континентальности климата и занимает крайнее южное положение на обследованной территории Южного Урала. В пределах степной континентальной области отчетливо выделяются две ландшафтные единицы: провинция Южно-Уральской возвышенности и Урало-Тобольская провинция Зауральского пенеплена.

Инвентаризационное изучение материалов фенологических данных по ландшафтным провинциям Урала выполнено на основе анализа архивных документов фенологической сети РГО в 2020 г. В качестве основного материала для анализа использованы данные по климатическим и фенологическим явлениям, характеризующим начало, середину и окончание весны: начало сокодвижения у березы (Betula pubescens; Betula Pendula Roth.), начало зеленения березы (Betula pubescens; Betula Pendula Roth.) и начало цветения черемухи (Padus avium Mill.). Обследовано более 45 тыс. бланков фенологической сети РГО, заполненных корреспондентами-наблюдателями в период с 1891 по 2007 г. по территориям Пермского края, Свердловской, Челябинской, Курганской, Оренбургской, Тюменской областей и Республики Башкортостан. Бланки наблюдений переведены в электронный формат, составлен реестр пунктов наблюдений по ландшафтным областям и провинциям Урала и таблицы по конкретным явлениям природы. Анализ фенологических материалов выполнен по двенадцати ландшафтным провинциям Северного, Среднего и Южного Урала в пределах трех ландшафтных областей.-

Максимальным напряжением и временной изменчивостью жизненных процессов в биоте характеризуется вегетационный период. К наиболее распространенным и надежно определяемым фитофенологическим явлениям в природе, которые интегрально характеризуют весенние гидрометеорологические условия, относятся зеленение березы бородавчатой (повислой) (Betula pubescens; Betula Pendula Roth.) и начало цветения черемухи обыкновенной (Padus avium Mill.). Многолетняя динамика сроков наступления данных фенофаз дает возможность оценить в первую очередь тенденции изменения термических условий весны $[10,11]$.

Методами изучения сезонной динамики традиционно являются полевые наблюдения, которые позволяют отслеживать ритмические изменения природных компонентов. В работе собраны данные по программам УОЛЕ, фенологической комиссии Всесоюзного географического общества, Русского географического общества и сети ООПТ Урала.

При описании сезонной динамики наибольшую ценность представляют длинные ряды наблюдений, сопоставимые с характерным временем развития геосистем. Подобные фенологические ряды накоплены классическим или первичным методом группы регистраторов срока, суть которого состоит в фиксации даты наступления явления на определенной территории и расчета средней даты наступления явления [12]. На следующем этапе для каждой провинции материал был проанализирован на дефектность. Даты, отклонения которых составили более \pm 3 суток от средних и явно аномальные, были исключены из базы данных. Для оптимизации сравнения показателей провинций произведен расчет широтного, долготного и высотного градиентов. При обработке результатов наблюдений оценены следующие параметры: средняя многолетняя дата наступления явления (X cp.), дисперсия $\left(\sigma^{2}\right)$, стандартное отклонение (ошибка) среднего значения $(\sigma)$ и крайние даты регистрации явления.

Характеристика динамики выполнена на основе расчетов линейных трендов по многолетним рядам наблюдений. Их достоверность непосредственно связана с репрезентативностью выборки, она существенно зависит от количества пропусков в изучаемых рядах. В ряде случаев не за все годы имеется достаточный массив информации. Оценка тренда проводилась методом наименьших квадратов, т.е. находилась линейная функция времени: $d^{*}(t)=A t+B$, которая наилучшим образом аппроксимирует временной ряд $\{d(t)\}$. Здесь $d(t)$ - дата (сутки в календарном году) сезонного явления в $t$-й год ( $\mathrm{t}$ - год наблюдения). Значение коэффициента А дает среднюю скорость изменения рассматриваемой характеристики (сут/год) на исследуемом отрезке времени [13]. 
Календарные даты переводились в непрерывные ряды путем отсчета от 1 марта [14]. Более раннее наступление явлений фиксируется отрицательным трендом, более позднее - положительным. Скорость изменения дат наступления явлений, характеризующая тренд по десятилетиям, рассчитывалась как средняя по провинции.

\section{Результаты исследования и их обсуждение}

За начало весны принимается устойчивый переход среднесуточной температуры воздуха через $0^{\circ}$. Средняя многолетняя дата перехода для исследуемых провинций 8 апреля. Устойчивый переход температуры через $0^{\circ}$ на изучаемой территории проходит всего за 14 дней, начиная с 3 апреля в Тагило-Пышминской провинции Зауральского пенеплена до 17 апреля в среднегорной Щугоро-Усьвинской провинции Северного Урала.

Скорость перемещения волны тепла с юга на север в восточных предгорьях составляет 286 км/сутки, в западных предгорьях 122 км/сутки. Медленнее всего идет перемещение тепла в горной полосе - 86 км/ сутки. Положительные температуры раньше устанавливаются на восточном склоне, что чаще всего связано с приходом тепла из Средней Азии.

Градиент перемещения тепла с восточного склона на западный максимальный на Северном Урале 1,4 суток $/ 1^{\circ}$ долготы $(2,5$ суток/100 км) и уменьшается на юг до 0,7 суток $/ 1^{\circ}$ долготы $(1,2$ суток/100 км) на Среднем Урале и 0,4 суток $/ 1^{\circ}$ долготы $(0,7$ суток/100 км) на Южном Урале.

Переход температуры чере $3+14^{\circ} \mathrm{C}$ совпадает с окончанием весны и устанавливается на исследуемой территории с 19 мая в Урало-Тобольской и Исетско-Уйской провинциях Зауральского пенеплена по 21 июня в Щугоро-Усьвинской провинции среднегорий Северного Урала. Таким образом, переход от весны к лету осуществляется за 33 дня.

Средняя продолжительность весны с юга на север увеличивается на 9 суток: в таежной области она составляет 64 суток, в лесостепной -55 , в степной -54 .

Сокодвижение у березы начинается 19 апреля в Урало-Тобольской провинции и заканчивается 28 апреля в Ятрия-Лобвинской провинции восточных предгорий Северного Урала, составляя на изучаемой территории 9 дней. Разница в сроках наступления сокодвижения, которое относится к началу весны, значительно меньше, чем у других весенних явлений. Скорость перемещения процесса с юга на север незначительная: в западных предгорьях 0,4 сут $/ 1^{\circ}$ широты, в восточных предгорьях - 1,1 сут/ $1^{\circ}$, а в горной полосе увеличивается до 1,2 сут/ $1^{\circ}$. Практически с одинаковой скоростью сокодвижение у березы перемещается с восточного склона на западный: на Северном Урале 40 км/сутки, на Южном - 38 км/ сут. На Среднем Урале разницы между Западными предгорьями и Зауральским пенепленом не прослеживается. Высотный градиент на Северном Урале самый низкий за сезон и составляет 1,3 сут/100 м. В большинстве изучаемых провинций, за исключением Ятрия-Лобвинской провинции восточных предгорий Северного Урала, выявлена прямая корреляция между суммой положительных температур и началом сокодвижения у березы от 0,53 до 0,91 . В среднем по изучаемым провинциям корреляция с датой перехода чере $3+5^{\circ} \mathrm{C}$ составляет 0,73 .

Фронт сезонного явления - начала зеленения березы - продвигается с юго-востока на северо-запад: оно начинается в Урало-Тобольской провинции Зауральского пенеплена 5 мая и заканчивается 27 мая в Щугоро-Вишерской провинции западных предгорий Северного Урала. Таким образом, зеленение по среднемноголетним срокам проходит за 22 дня. Явление начинается на восточном, более теплом и сухом склоне Урала, лежащем в барьерной тени от горной полосы. Здесь выпадает осадков на 200-250 мм меньше, чем на западном склоне, и на 500 мм меньше, чем в горной полосе. Затем зеленеет береза в западных предгорьях, где высота снежного покрова больше на 30-50 см, чем в восточных предгорьях, чаще наблюдается циклональная погода и больше тепла расходуется на таяние снега.

При продвижении к северу наступление зеленения березы запаздывает в провинциях западных предгорий на 2,5 сут/ $1^{\circ}$ широты или на 2,2 сут/100 км. В горной полосе эта разница составляет 2,2 сут/ $1^{\circ}$ (2,0 сут/100 км); в восточных предгорьях она уменьшается до 0,9 сут $/ 1^{\circ}(0,8$ сут/100 км).

В целом береза зеленеет раньше в провинциях восточных предгорий. Продвижение зеленения с востока на запад идет на $\mathrm{Ce}-$ верном и Южном Урале со скоростью 29 км/ сут и 30 км/сут соответственно, на Среднем Урале в 1,5 раза медленнее - 47 км/сут. 
Связь зеленения березы с переходом среднесуточных температур воздуха через $+10^{\circ} \mathrm{C}$ и $+12{ }^{\circ} \mathrm{C}$ по провинциям Урала составляет от 0,89 и 0,87 соответственно. Зависимость от суммы положительных температур также прослеживается повсеместно, за исключением Восточной предгорно-среднегорной провинции Южного Урала и Исетско-Уйской провинции Зауральского пенеплена.

Лучшие результаты для анализа весенних явлений дают показатели цветения черемухи. Они представлены в максимальном объеме во всех изучаемых провинциях Урала. Разница между датами наступления зеленения березы и цветения черемухи на Среднем и Южном Урале составляет 4-8 суток, а на Северном Урале 6-14 суток. Аналогично зеленению березы, цветение черемухи начинается 7 мая в Урало-Тобольской провинции и заканчивается 8 июня в Щугоро-Усьвинской среднегорной провинции Северного Урала. Продолжительность цветения составляет 32 дня. Быстрее, за 14 суток, оно проходит в восточных предгорьях Урала. В провинциях западных предгорий и горной полосе - за 22-23 дня. Скорость наступления цветения черемухи с юга на север несколько больше, чем для процесса зеленения березы. Максимальная скорость наблюдается в западных предгорьях и на Зауральском пенеплене: 2,9 сут $/ 1^{\circ}$ широты $\left(2,6\right.$ сут/100 км) и 3,4 сут/ $1^{\circ}(3,1$ сут/100 км $)$ соответственно. В горной полосе она составляет 3,2 сут $/ 1^{\circ}$ (2,8 сут/100 км). Минимальная скорость в провинциях восточных предгорий $-1,8$ сут/1 ${ }^{\circ}$ (1,6 сут/100 км).

Гораздо большая разница в наступлении цветения наблюдается при движении с востока на запад особенно на Северном Урале: 4,5 сут/100 км, при этом разница в зацветании черемухи в Щугоро-Вишерской провинции западных предгорий и среднегорной Щугоро-Усьвинской провинции Северного Урала составляет 9 суток, а с Ятрия-Лобвинской провинцией восточных предгорий - 18 суток. На Южном Урале аналогичная разница между горной полосой и предгорьями 5 суток, а на Среднем Урале - 4. Высотный градиент на Северном Урале увеличивается в 2 раза по сравнению с сокодвижением березы и составляет 2,7 сут/100 м.

Коэффициент корреляции явления с переходными температурами $+5^{\circ} \mathrm{C},+10^{\circ} \mathrm{C}$ и $+12^{\circ} \mathrm{C}$ выше, чем у других весенних явлений, и составляет $0,94,0,93$ и 0,86 со- ответственно. Сумма положительных температур определяет даты начала цветения черемухи в среднегорной Щугоро-Усьвинской провинции Северного Урала, в провинциях восточных предгорий $\mathrm{Ce}$ верного и Среднего Урала, а также в Тагило-Пышминской провинции Зауральского пенеплена.

Анализ многолетних рядов позволил рассчитать линейные тренды для метеорологических и фенологических явлений. Тренд среднегодовой температуры воздуха в ландшафтных провинциях Урала (рис. 1) имеет повсеместно отрицательную направленность, однако его значения различны - в провинциях степной области Южного Урала они составляют от $-0,31$ до $-0,41^{\circ} \mathrm{C} / 10$ лет, в западных предгорьях, в низкогорьях Среднего Урала, в среднегорьях Северного Урала и их восточных предгорных провинциях скорости изменения температур колеблются в пределах от $-0,11$ до $-0,21^{\circ} \mathrm{C} / 10$ лет.

Выявлены тенденции смещения сроков начала весенних событий у изучаемых древесных видов растений в провинциях Урала. Для дат зеленения листьев березы имеет место отрицательный тренд повсеместно, кроме восточной предгорносреднегорной Южного Урала (до 2-6 суток за весь изучаемый период). Минимальными значениями тренда характеризуется среднегорная Щугоро-Усьвинская провинция Северного Урала, максимальными - провинции Среднего Урала и его предгорий. При этом Тагило-Пышминская и Исетско-Уйская провинции отличаются слабо выраженной скоростью тренда до 0,7 сут/10 лет (рис. 2).

Начало цветения черемухи характеризуется отрицательными значениями тренда, за исключением среднегорной ЩугороУсьвинской провинции Северного Урала, где устойчивый положительный тренд отмечен замедлением сроков наступления явления со скоростью 0,2 сут/10 лет (рис. 3). В отличие от ранневесеннего зеленения листьев березы, отрицательные тенденции трендов имеют незначительные показатели - от 0,2 до 2 сут/10 лет, в среднем по провинциям 0,5 сут/10 лет. Максимальные отрицательные тренды выявлены в восточной предгорно-среднегорной провинции Южного Урала - до 1,9 суток за период исследования. Практически не выражены изменения в сроках цветения черемухи на территории Исетско-Уйской провинции Зауральского пенеплена. 


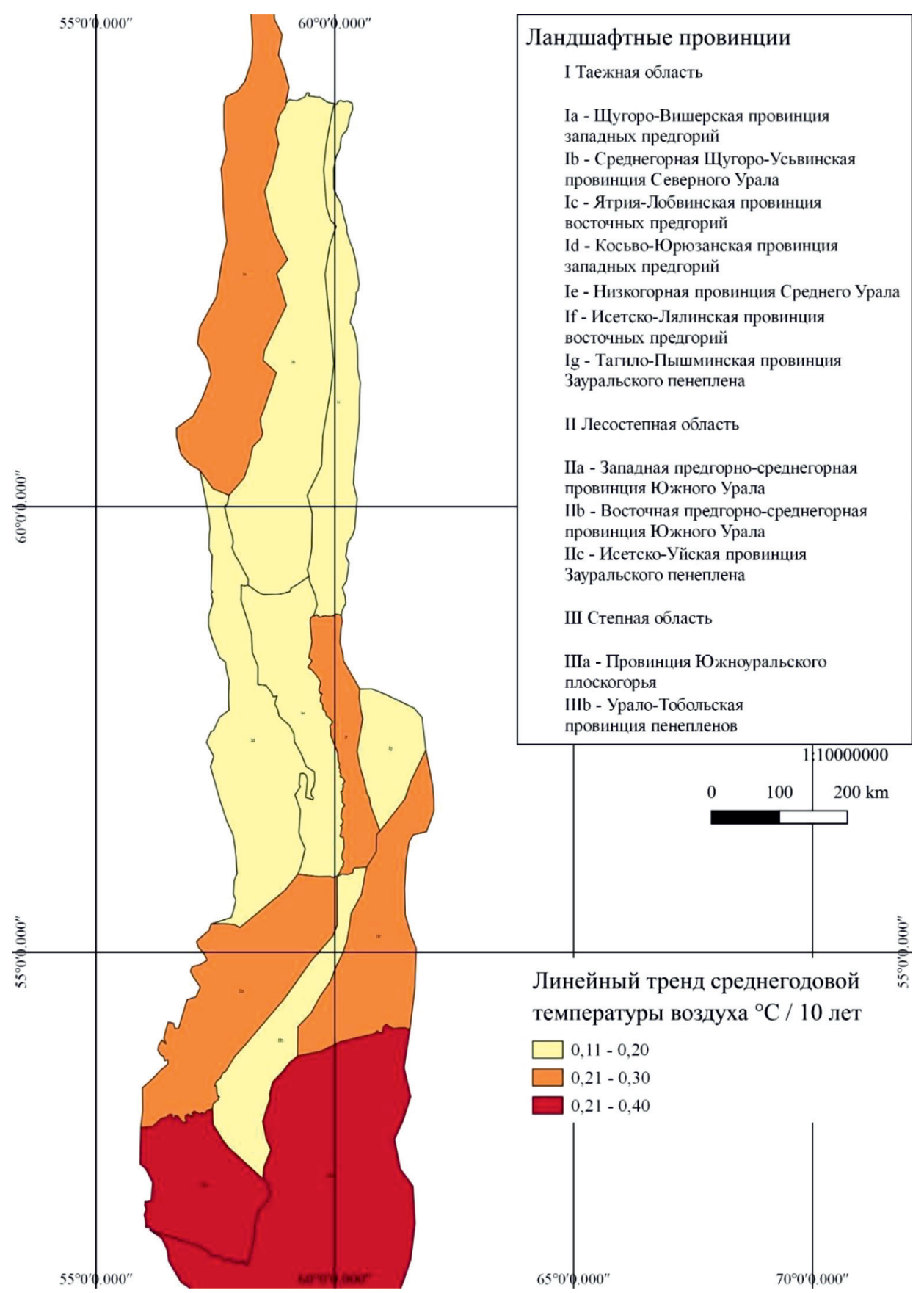

Рис. 1. Линейный тренд среднегодовой температуры воздуха в провинциях Урала

\section{Заключение}

Ландшафтная структура Урала определяется основными закономерностями физико-географической дифференциации. Зональность, секторность, тектогенная, высотно-поясная, барьерная и солярно-экспозиционная дифференциация обусловливают неоднородность ланд- шафтного строения и пространственную изменчивость сложности и разнообразия ландшафтной структуры внутри исследуемой территории. Из названных закономерностей определяющее влияние на сложность и разнообразие ландшафтной структуры оказывает тектогенная дифференциация, далее идет зональность, и относительно меньше выражена сектор- 
ность. Наибольшее разнообразие ландшафтной структуры в пределах исследуемой территории характерно для горных таежных умеренно континентальных провинций, наименьшее - для равнинных лесостепных континентальных.

В условиях ландшафтного разнообразия Урала в период с 1925 по 2019 г. наблюдаются тенденции к более раннему наступлению метеорологических и фитофенологических весенних событий. Наступление сезона маркирует устойчивый переход температуры через $0^{\circ}$, начинаясь на юго-востоке изучаемой территории, он заканчивается в среднегорьях Северного Урала в течение 14 дней. В начале весны величины широтного, долготного и высотного градиента незначительны, к середине весны они увеличиваются.

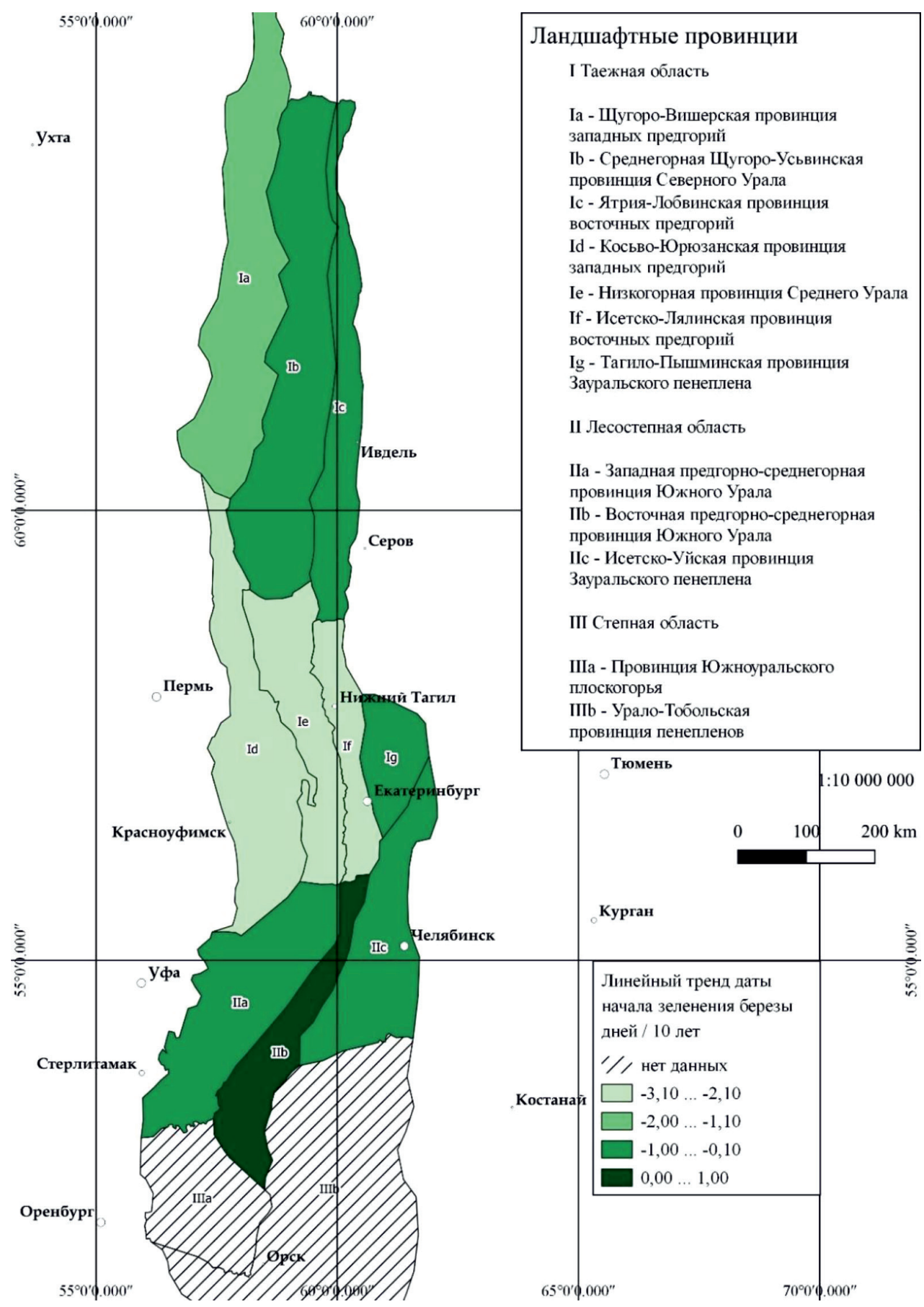

Рис. 2. Линейный тренд даты начала зеленения березы в провинциях Урала 


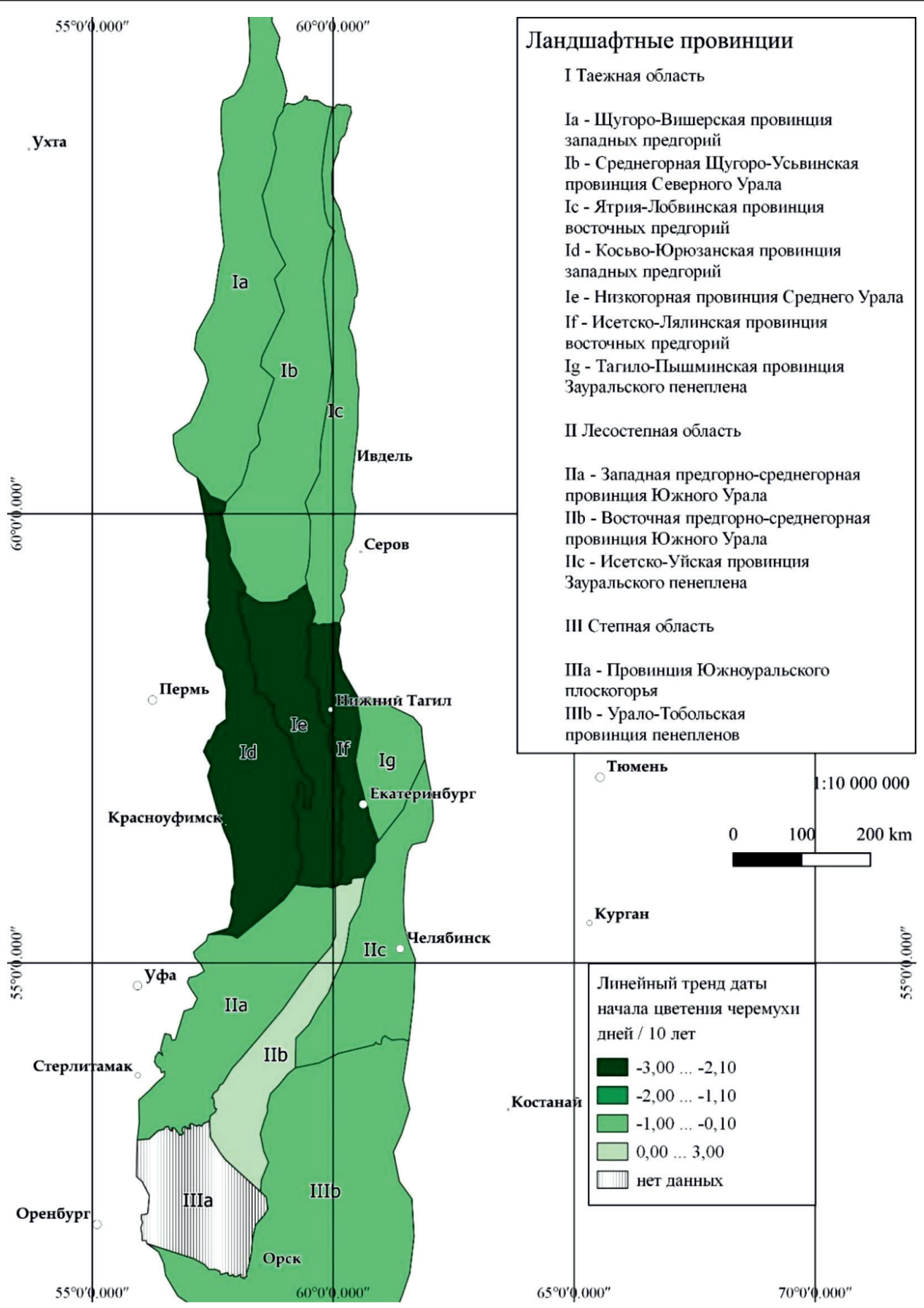

Рис. 3. Линейный тренд даты начала ияветения черемухи в провинциях Урала

В большинстве провинций Урала установлена линейная взаимосвязь между датами наступления явлений-феноиндикаторов с переходом через температурные рубежи и с нарастанием сумм положительных температур. Отрицательные тренды наступления зеленения березы и цветения черемухи показывают разные скорости изменения сроков их наступления по провинциям, однако реакции данных видов в целом отражают общую тенденцию изменения термического режима на Урале. Тенденции изменения фитофенологических показателей в ландшафтных провинциях Северного, Среднего и Южного Урала в обобщенном виде могут служить индикаторами потепления климата региона. 


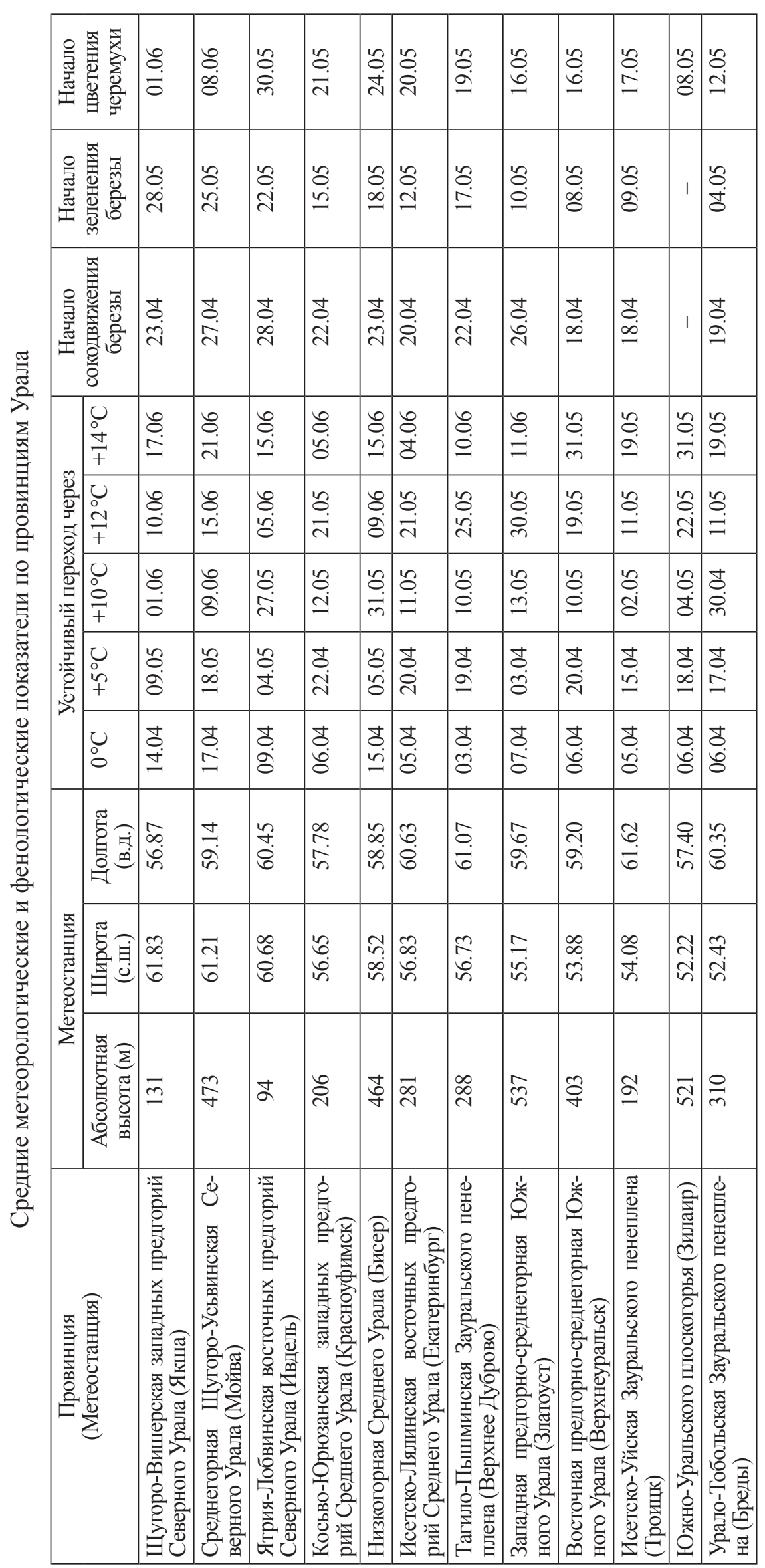


Исследование выполнено при финансовой поддержке Русского географического общества в рамках договора № 03/2020-P.

\section{Список литературы / References}

1. Второй оценочный доклад Росгидромета об изменениях климата и их последствиях на территории Российской Федерации: общее резюме. М., 2014. 60 c.

The second assessment report of Roshydromet on climate change and its consequences on the territory of the Russian Federation: general summary. M., 2014. 60 p. (in Russian).

2. Минин А.А., Воскова А.В. Гомеостатические реакции растений на современные изменения климата: пространственно-фенологические аспекты // Онтогенез. 2014 № 3 (45). C. 162-169.

Minin A.A., Voskova A.V. Homeostatic responses of plants to modern climate changes: spatial and phenological aspects Ontogenez. 2014. № 3 (45). P. 162-169 (in Russian).

3. Минин А.А. Некоторые аспекты взаимосвязей наземных экосистем с изменяющимся климатом // Успехи современной биологии. 2011. № 131 (4). С. 407-411.

Minin A.A. Some aspects of the relationship of terrestria ecosystems with a changing climate // Uspekhi sovremennoi biologii. 2011. № 131 (4). P. 407-411 (in Russian).

4. Чибилёв А.А., Весёлкин Д.В., Куянцева Н.Б., Чащина О.Е., Дубинин А.Е. Динамика числа лесных пожаров и климата Ильменского заповедника в 1948-2013 гг. // Доклады Акад. Наук. Т. 468. 2016. № 5. С. 575-578.

Chibilev A.A., Veselkin D.V., Kuyantseva N.B., Chaschina O.E., Dubinin A.E. Dynamics of the number of forest fires and the climate of the Ilmen Reserve in 1948-2013 // Doklady Akad. Nauk. T. 468. 2016. № 5. P. 575-578 (in Russian)

5. Шакиров А.В. Физико-географическое районирование Урала. Екатеринбург: УрО РАН, 2011. 617 с.

Shakirov A.V. Physico-geographical regionalization of the Urals. Ekaterinburg: URO RAN, 2011. 617 p. (in Russian).

6. Гурьевских О.Ю., Капустин В.Г., Скок Н.В., Янцер О.В. Физико-географическое районирование и ландшафты Свердловской области. Екатеринбург: ФГБОУ ВО Урал. гос. пед. ун-т, 2016. 280 с.

Gur'evskikh O.Yu, Kapustin V.G., Skok N.V, Yantser O.V. Physico-geographical regionalization and landscapes of the Sverdlovsk region. Yekaterinburg: FGBOU VO Ural. gos. ped. un-t, 2016. 280 p. (in Russian).

7. Хорошев А.В. Полимасштабная организация географического ландшафта. М.: Товарищество научных изданий KMК, 2016. 416 c.
Khoroshev A.V. Multiscale organization of landscape. M.: Tovarischestvo nauchnykh izdanii KMK, 2016. 416 p. (in Russian).

8. Прокаев В.И. Физико-географическое районирование: учеб. пособие для студентов пед. ин-тов. М.: Просвещение, 1983. $176 \mathrm{c}$

Prokaev V.I. Physico-geographical regionalization: ucheb. manual for students of pedagogical institutes. M.: Prosveschenie, 1983. 176 p. (in Russian).

9. Соловьев А.Н. Биота и климат в ХХ столетии. Региональная фенология. М.: Пасьва, 2005. 288 с.

Solov'ev A.N. Biota and climate in the XX century. Regional phenology. M.: Pas'va, 2005. 288 p. (in Russian)

10. Минин А.А., Ранькова Э.Я., Буйволов Ю.А., Спаельникова И.И., Филатова Т.Д. Фенологические тренды в природе центральной части Русской равнины в условиях современного потепления // Жизнь Земли. Том 40. 2018. № 2. С. $162-174$.

Minin A.A., Ran'kova Eh.Ya., Buivolov Yu.A., Spael'nikova I.I., Filatova T.D. Phenological trends in nature of the central part of the russian plain under the conditions of modern warming // Zhizn' Zemli. Tom 40. 2018. № 2. P. 162-174. (in Russian).

11. Янцер О.В., Скок Н.В. Фенологические методы исследований в изучении динамики ландшафтов: общий обзор // Вестник Башкирского университета. 2016. Т. 21. № 1. C. $91-100$.

Yantser O.V., Skok N.V. Phenological research methods in the study of landscape dynamics: an overview // Vestnik Bashkirskogo universiteta. 2016. Vol. 21. № 1. P. 91-100 (in Russian).

12. Минин А.А., Ранькова Э.Я., Рыбина Е.Г., Буйволов Ю.А., Сапельникова И.И., Филатова Т.Д. Феноиндикация изменений климата за период 1976-2015 гг. в центральной части Европейской территории России: береза бородавчатая (повислая) (Betula verrucosa Ehrh. (B. pendula Roth.)) // Проблемы экологического мониторинга и моделирования экосистем. 2016. Т. 27. № 2. С. 17-28.

Minin A.A., Ran'kova Eh.Ya., Rybina E.G., Buivolov Yu.A., Sapel'nikova I.I., Filatova T.D. Phenoindication of climate change for the period 1976 to 2015 in the central part of European Russia: birch (silver birch) (Betula verrucosa Ehrh. (B. pendula Roth.)) // Problemy ehkologicheskogo monitoringa i modelirovaniya ehkosistem. 2016. Vol. 27. № 2. P. 1728 (in Russian).

13. Зайцев Г.Н. Математическая статистика в экспериментальной ботанике. М.: Наука, 1984. 424 с.

Zaitsev G.N. Mathematical statistics in experimental botany. M.: Nauka, 1984. 424 p. (in Russian). 